\title{
The Effect of the School Internal Environment of Secondary Education on Daily Work of Teaching Staff: A Systemic Approach
}

\author{
Msc. Siatira Stavroula \\ Senior High School Teacher, 3rd Lyceum of Karditsa, Karditsa, Greece \\ stsiatira@sch.gr
}

\section{Dr. Sdrolias Labros}

Assoc. Professor, Dept. of Business Administration, TEl of Thessaly, Larissa, Greece

Isdrolias@teilar.gr

\section{Dr. Aspridis Georgios}

Ass. Professor, Dept. of Business Administration, TEl of Thessaly, Larissa, Greece aspridis@teilar.gr

\section{Dr. Papadimopoulos loannis}

Professor, Dept. of Business Administration, TEl of Thessaly, Larissa, Greece

Doi:10.5901/mjss.2014.v5n13p244 papadimopoulos@teilar.gr

\section{Abstract}

This article focuses on exploring the School Internal Environment and on identifying disorders that appear in the workplace of the Teaching Staff of Secondary Education, in order to record the effects of these problems in natural (physical) and mental balance and health of the teachers. It is based on a sample of 188 teachers, 65 men (34.6\%) and 123 women (65.4\%) who work in High and Senior High Schools of the city of Karditsa (Thessaly, Greece). It focuses most on the effect of the Schools' Location, the Schools' Organizational and Operational Structure, the Head Teachers, the Schools' Human Resources as well as the Media and the Teaching Methods of the Personnel in their daily work. The results demonstrate especially that the Head Teachers' institutional weakness to control the students' behaviour and the school internal physical and psychological climate affect negatively the teachers' daily work. On the other hand, especially the development of educational projects, the location (site of installation) of the school unit, the Head teachers' incentive policy and both the Head teachers' and the colleagues' behaviour affect positively the teachers' daily work. Finally, the findings shed light on the factors that can contribute to the creation of necessary conditions which could improve the working environment of the Teaching Staff of Secondary Education.

Keywords: School Unit, Environmental Systemic Approach, Teaching Staff, Workplace, Mental and Physical Effects, Work Performance.

\section{Introduction}

With the word "Environment" of a school organization is what is located outside and inside of the "systemic" limits of its body and is divided into Internal and External (Saitis, 2008: 32-39). The External Environment refers to different variables that exist and act outside of the school unit's boundaries and interacting with it. The Internal Environment consists of specific factors, which in one way or another affect the organization, the function, the behaviour and the effectiveness of it. These are the Location, the Organizational and the Operational Structure of the school unit, the Head Teachers, the schools' Human Resources, the Audiovisual and Teaching Methods etc. The examination of these factors under the view of their impact on teachers is significant and therefore necessary.

It has been argued that the design of the built environment of an organization influences the physical and mental health of its members (Dannenberg et al., 2003). The location of the school unit, as a living organism, is a matter which is related to factors such as social, economic and spatial structure of a region (the transportation network which serves teachers and students, the distance from the centre of a region, the place (location) of school building's installation (Kouri, 1999; Pucher \& Dijkstra, 2003). Indeed it has been observed thanks to researches that in areas with low social and economic level more problems are manifested in the function of school units than in a school in an upgraded, better and 
socially homogeneous area (Saitis, 2008). Finally, various physical factors, such as cold, heat, noise and poor yard impact negatively on teachers' and students' health and consequently on their performance (Buckley, Schneider \& Shang, 2005; Saitis, 2008; Schneider, 2003; Uline \& Tschannen-Moran, 2008).

Regarding the organizational and operational structure of a school unit it is assumed that its size is determined by the size of the students' population. In Secondary Education it has been argued that an effective size may include 400800 students. Findings from research projects about the productive function of schools give some evidence that the moderate-sized schools (400-800 students) can balance in the best way the reduction of their operating costs with the possible negative effects of large schools (Andrews, Duncombe \& Yinger, 2002). In small schools, where there is usually a family atmosphere, teachers and even those who are at the beginning of their careers, feel a degree of autonomy and freedom for action, so they can have a better performance (Hargreaves, 2006).

In addition, the Management of a school unit is one of the major factors that influence its character. The decisionmaking process and the existence of a positive climate that is created and maintained, first of all, by the Principal, is associated with its effectiveness (Berry, Smylie \& Fuller, 2008; Coleman \& Collinge, 1991; Saitis, 2008). The skillful leadership is a key factor which explains the successful changes (Hallinger, 2003; Supovitz \& Turner, 2000). Mostly, the management carries a great load for inspiring to any individual both an educational and communicative climate (Athanasoula-Reppa, 2008), while the positive attitude of the school Head teachers contributes to the teachers' with little experience professional development (Delvaux et al., 2013).

The role of Human Resources is also important in a school unit. It is about teachers who work, students who attend lessons and the support staff. Firstly, it should be noted that the teachers' personal characteristics, such as gender, age, physical characteristics, aspirations, specificity, etc., affect their behaviour and at the same time the decisions they make in the school unit where they work. In addition to this, the good cooperation between the human resources of a school unit also increases its effectiveness (Berry et al., 2008; Smilansky, 2011; Uline \& TschannenMoran, 2008). On the contrary, the social relations of low confidence in a school unit have negative effect on teachers' physical and emotional health and increase the stress coming from work (Troman, 2000; Van Dick \& Wagner, 2001).

You should also note that the teaching techniques help teachers to carry out their teaching duties. The nature of the lessons and the technological equipment affect the quality of teaching and of course, the teachers' effectiveness and create a positive environment in the classroom, which in turn has a beneficial effect on teachers and learners (Saitis, 2008). Nowadays, the teacher has many opportunities using the PC and the Internet to create a new climate in the classroom that does not leave unaffected both himself and the student by removing them from the monotony and boredom (Jenkins, Clinton, Purushotma, Robison \& Weigel, 2009). The classroom is a place where the teacher has the freedom to use teaching methods and techniques that make more effective the transmission of knowledge and increase his self-efficacy (Berry et al., 2008; Burkhardt \& Schoenfeld, 2003).

The Environment of the Greek School Units, especially that of Secondary Education, has been changed radically in the last 45 or so years and in fact unfortunately, apart from few exceptions, for the worse. The deliberate, by international and domestic interests, "Americanization" of school units based on the operation standards "of segregated" schools that targets to poor American social classes, the unstable Educational System in which each Government or even any new leadership of the Ministry of Education introduce untested and unevaluated systems, the depreciation of administrative hierarchy and performance tests, the decriminalization of everything and the leveling of students' performance incentives, have created a very difficult working environment for educational offer.

The city of Karditsa is perhaps the most representative area of Greek territory for a systematic study and record of the effect from transition to newly formed operating conditions of school units and therefore of the effect of internal school factors in the working environment of teaching staff, that tries to "balance" between the "creative" past and the "flattening" present and even more the "bleak" future. Schools in this region still maintain the reputation of the units with the most successful performance of their students on the entrance exams at various universities in the country and on various domestic and international competitions, while they are considered that they have not been alienated at a big extent so far by the new conditions expressed above perhaps because of strong traditions and values.

\section{Theoretical Approach}

The following apposition of literatures presents the disorders on mental and natural (physical) balance and health of teaching staff (mental and psychosomatic disorders) associated with factors in the internal school environment (Wakefield, 1992). Regarding the first ones are under investigation, especially in the last decade, the anxiety, the depression, the mental alienation, the in-school violence and the burnout syndrome (Bauer et al., 2007; Chatzichristou, 2004; Pappa, 2006). While, regarding the latter, are under investigation the natural elements of the working environment, 
such as the design and the conditions of classrooms, the proper lighting, the heating and cooling conditions, the hygiene conditions, the natural (physical) intensity of teachers' work, the security of the school premises, etc. (Shalley, Zhou \& Oldham, 2004).

\subsection{Mental Disorders}

In the workplace the mental burden of the employee brings indifference to perform tasks, isolationist tendencies, alienation from the work, lack of moral satisfaction and joy to work. All these are undoubtedly symptoms of mental alienation from work (Sdrolias, Terzidis \& Polyzos, 2003). In particular, the mentally alienated teacher feels unable to impersonate the role that has been determined to take (Cox \& Wood, 1980). What is highlighted in all the researches is that the process of teachers' socialization leads to the compliance (active or passive), the retreat, the compromise and generally to the acceptance of traditional beliefs and principles. The teachers' dependence and the compliance to bureaucratic hierarchy lead to personal alienation (Shannon, 2000). Another cause for teachers' mental alienation is also the lack of an effective correlation and interaction between them (Kountouras, 1985).

About the school climate it has been told the fact that teachers often did not know their students is a very old observation. But the fact that teachers themselves do not know each other well, because their presence in the school coincides with the teaching activity, is a new finding (Gotovos, Mavrogiorgos \& Papakonstantinou, 2000: 96). The research evidence suggests that, when the school climate becomes more supportive, the teachers become progressively less alienated (Thomson \& Wendt, 1995; Van Dick \& Wagner, 2001).

Furthermore, the teachers' stress is a negative emotion associated with their profession and relates to emotions, such as anger, tension, emptiness, depression and they are a threat to self-esteem and good teachers health condition (Howard \& Johnson, 2004). Teaching is stressful (Chapain, 2008; Hanaken, Bakker \& Schaufeli, 2006; Kokkinos, 2007; Van Dick \& Wagner, 2001). Highlights of teachers, according to Olivier and Venter (2003), are emotional events (they show the ways in which teachers react because of tension in their school, e.g. depression, anxiety), fatigue events ( $p$. example sleep habits, exhaustion), cardiovascular events (e.g. blood pressure, increased heartbeats), culinary events (e.g. stomach pains, cramps) and behavioral manifestations (e.g. use of prescribed drugs, consumption of alcohol).

Also it must be emphasized that the profession of teaching occupies a leading position in the list of stressful jobs, and the teachers belong to the group of professionals who are highly prone to the syndrome of burnout. The causes for the appearance of this syndrome are investigated both: to the structure and to the function of the education system and to the teacher's personality and characteristics. The teacher who has the burnout syndrome is dominated by feelings of anxiety, loses his interest in teaching and positive feelings about the students, creates a negative image about himself and fails to face the problems that come up during the educational process (Platsidou \& Agaliotis, 2008).

Teachers who feel anxious show aggressive behaviour towards students. Moreover, they express confusion, avoidable behaviour, absenteeism from their workplace and reduction to the performance of both, themselves and their students, a fact that is mainly caused by the lack of creativity and by non-implementation of effective teaching techniques (Bauer et al., 1996). Compared to other professions, teachers have high levels of exhaustion and cynicism, which constitute the 'core' of burnout. The depletion refers to the feeling of the chronic fatigue that a working man feels, especially the teacher. The cynicism refers to the loss of interest in work and to the estrangement from their colleagues (Hanaken et al., 2006).

Furthermore, the depression is considered to be the most unfavorable mental impairment to the working man (Tennant, 2001). Precursor of the depression that is associated with this syndrome is considered to be burnout (Baba, Galperin \& Lituchy, 1999; lacovides, Fountoulakis, Moysidou \& Lerodiakonoy, 1999; Maslach, 1987; Tennant, 2001). Symptoms of teachers' depression appear to be four types. There are mental symptoms (prolonged sadness, frustration), behavioral (psychomotor retardation, lack of pleasure, loss of interest), cognitive (emotions related to a sense of lack and loss) and biological (decrease in irritability of the nervous system, slowing down of operations and movements). Unfortunately, the depression affects greatly the interpersonal relationships and the work environment of the individual who suffers from this (Papastylianou, Kaila \& Polychronopoulos, 2009).

Teachers' mental health may also play an important role in the relations with students. Teachers who most often present symptoms of depression and have low self-efficacy are teachers who provide little emotional support in their classroom and tend to engage in confrontations and conflicts with students and as a result it becomes very difficult for them to control and manage students (Hamre, Pianta, Downer \& Mashburn, 2008). In addition, many teachers in recent years complain about the school violence and seek assistance by taking both preventive and repressive measures (Mallet \& Paty, 1999). It is undisputed that the in-school violence has serious negative implications for the teacher and that the teacher who faces such violence often absents himself from work and thinks about his disengage from his 
workplace. It has even been found that certain forms of school violence are a major factor of the teacher's intention to leave and take early retirement (Galand, 2007).

\subsection{Causes of Natural (Physical) or Psychosomatic Disorders}

The prevalence of tension and anxiety in the teachers work is supported by research findings which show that a quarter of teachers evaluate teaching as "very or extremely stressful". The chronic stress leads to emotional, behavioral and physical exhaustion. The emotional intensity that teachers face (stress, anxiety, frustration, nervous tension, wear) introduce natural (physical) and mental disorders (Kyriacou, 2001). The chronic exposure of teacher in stressful conditions directly affects health. The way in which the teacher faces the stress may change the way he feels, thinks or behaves (Glaretzou, 2011).

Furthermore, the working conditions, such as heat, inadequate lighting and noise not only cause dysphoria but also affect the health, the safety and the productivity of each working man. Although these conditions cause a problem to the senses, to vision and hearing, they are not often taken into account (Greek Ministry of Employment, 1992). Finally, the safety and hygiene conditions affect the school climate in a catalytic way and teachers in particular (Horne-Martin, 2005; Organization for Economic Cooperation and Development, 2007; Schneider, 2003). It is argued that working conditions affect them even more than their economic earnings (Berry et al., 2008).

Furthermore, about the noisy situation in the classrooms, the teachers' attempt to cope with it has health consequences (Schneider, 2002; 2003; Kampourakis, 2005: 1-5). The noise causes misunderstanding and can lead to permanent hearing loss. Moreover, as the number of students in class grows, the noise level in the classroom increases and this complicates the teachers' task of teaching (Horne-Martin, 2005; Schneider, 2002; Shield \& Dockrell, 2004). Additionally, the poor technological equipment and the school building (size, orientation, lighting, noise levels, temperatures, hygiene and safety, gym and multi-purpose hall, an appropriate school yard, library, laboratories, offices, and the overall aesthetics and topography) construct a social and psychological environment that influences in a catalytic way the school culture (Horne-Martin, 2005; Supovitz \& Turner, 2000). Finally, the schools configuration, noise, heat, cold, light and air quality affect obviously the ability of teachers and students to carry out their duties. The fresh air, the good lighting and a quiet, comfortable and safe learning environment are necessary for the good performance of teachers and students (Schneider, 2002).

\subsection{Research Model and Research Hypothesises}

Since, as it was mentioned above, that the aim of this research is to determine the effect of internal school factors on the working environment of the teaching staff (here in particular at the city of Karditsa), it is attempted to gather primary data through a structured questionnaire, to give answers to a number of research questions-hypothesises such as what are now the dominant factors of internal school environment that affect the teachers' workplace, how they affect them and therefore what are the consequences of these effects on the mental and natural (physical) balance, and to determine what needs to be addressed or even improved at the school environment and, consequently, in all schools of the country.

\section{Research Methodology}

\subsection{The Sample of Research}

The population for research is secondary teachers, who perform administrative and teaching duties in the city of Karditsa. In the schools of this city their power according to elements of school units on September 2013 for High schools was 204 teachers and for Senior High Schools and Technical Schools was 248 teachers. Totally, 452 teachers work in the aforementioned schools. Based on the demographics of the research the sample is consisted of 188 teachers of Secondary Education, 65 men (34.6\%) and 123 women (65.4\%). Of these only $2.1 \%$ of the sample (4 people) have age less than 37 years, 72 people (38.3\%) have age from 38 to 46 years, 85 people (45.2\%) have age from 47 to 55 years and 27 people (14.4\%) have age over 56 years.

The analysis also shows that in the above sample only $6.4 \%, 12$ people have M.Sc. in addition to the first degree that is from Higher Education. The presentation of respondents' working years is also helpful. It shows that $14.4 \%$ have experience less than 10 years, 39.4\% have experience of $11-18$ years, $26.6 \%$ have experience of $19-26$ years and $19.7 \%$ have more than 27 experience years. Additionally, it must be noted that of the total sample a rate of $6.4 \%, 12$ people, have positions of responsibility and they are members of the school units Directorate. 


\subsection{The Questionnaire: Structure, Reliability and Process of Analysis}

The Questionnaire that was constructed includes closed-type questions and specifically questions of an assessment scale (it has been used the five points scale of Likert) and dichotomous questions (for simple and multiple choice). The questionnaire is structured in two parts. The first includes and searches demographic and other information from respondents, such as the gender, the age, the years of working experience, the level of education, the specialization, the type of duty (educational or administrative), the category of schools that they work, the family situation. The second includes questions to investigate the influence of factors from internal school environment on teachers' workplace.

After the collection of the questionnaires, the questions were codified and then the answers were analyzed with the statistical program SPSS 17 (Statistical Package for Social Sciences). Specifically, when analyzing the results they were mainly used the Mean, the Standard Deviation, the Frequencies, the Correlations, as well as the Reliability Coefficient (Cronbach's a) for measuring the reliability of the survey sample. For items on the Second Unit of Questionnaire the reliability index $a$ is high, $\mathbf{0 . 8 3}$ (must $a \geq 0.700$ ), which indicates that the Questionnaire module has good reliability (Bishop et al., 2007; Hair et al., 2010).

\subsection{Statistical Analysis of Questionnaire}

The Table below (Table 1) shows the Mean and the Standard Deviations of questions relating to the extent of the influence of internal school factors on teaching duties. Furthermore, observing the results of the Frequency of responses about specific questions in the Questionnaire, it is possible to come on conclusions about the effect of the internal environment on Teaching Staff.

Table 1: The Mean and the Standard Deviations of Questions

\begin{tabular}{lcc}
\hline Questions relating to the extent of the influence of internal school factors on teaching duties & Mean & Standard Deviations \\
\hline Q.1.1.b.Location (site of installation)/ Close Environment of the school unit & 3.05 & 1.38 \\
Q.1.2.b.Building / Hygiene Conditions & 3.52 & 1.13 \\
Q.1.3.b.Organizational / Operational Structure of the school unit & 3.95 & 0.98 \\
Q.1.4.b.Behaviour of the Principal & 3.83 & 1.03 \\
Q.1.5.b.Behaviour of the Colleagues & 3.66 & 1.14 \\
Q.1.6.b.Behaviour of the students / student councils & 3.09 & 1.25 \\
Q.1.7.b.Students' performance & 3.80 & 0.92 \\
Q.1.8.b.Head teachers' institutional weakness to control the students' behaviour & 3.44 & 1.04 \\
Q.1.9.b.Technological Equipment / Support Staff & 3.72 & 0.99 \\
Q.1.10.b.Development of Learning Projects & 2.88 & 1.23 \\
Q.1.11.b.Evaluation of teachers and educational work & 2.82 & 1.25 \\
Q.1.12.b. Head teachers' Incentive Policy & 2.68 & 1.20 \\
Q.1.13.b.The in-school natural (physical) climate & 3.20 & 1.12 \\
Q.1.14.b.The in-school psychological climate & 3.52 & 1.10 \\
\hline
\end{tabular}

Below, Table 2, they are presented the teachers' various aspects for specific factors of Internal School Environment.

Table 2: Teachers' Opinion of Internal School Environment Factors

\begin{tabular}{lccc}
\hline \multirow{2}{*}{ Factors of Internal School Environment } & \multicolumn{3}{c}{ Teachers' various aspects \% } \\
& Positive & Neutral & Negative \\
\hline Q.1.1.b.Location (site of installation) / Close Environment of the school unit & 75.5 & 21.8 & 2.7 \\
Q.1.2.b.Building / Hygiene Conditions & 52.1 & 29.8 & 18.1 \\
Q.1.3.b.Organizational / Operational Structure of the school unit & 73.9 & 24 & 2.1 \\
Q.1.4.b.Behaviour of the Principal & 77.1 & 18.6 & 4.3 \\
Q.1.5.b.Behaviour of the Colleagues & 78.7 & 19.2 & 2.1 \\
Q.1.6.b.Behaviour of the students/student councils & 30.9 & 53.7 & 15.4 \\
Q.1.7.b.Students' performance & 54.8 & 37.2 & 8 \\
Q.1.8.b.Head teachers' institutional weakness to control the students' behaviour & - & 21.3 & 78.7 \\
Q.1.9.b.Technological Equipment / Support Staff & 31.4 & 35.1 & 33.5 \\
Q.1.10.b.Development of Learning Projects & 42.6 & 39.8 & 17.6 \\
Q.1.11.b. Evaluation of teachers and educational work & 27.7 & 45.7 & 26.6
\end{tabular}




$\begin{array}{lcrr}\text { Q.1.12.b. Head teachers' Incentive Policy } & 28.2 & 56.4 & 15.4 \\ \text { Q.1.13.b.The in-school natural (physical) climate } & 13.8 & 46.3 & 39.9 \\ \text { Q.1.14.b.The in-school psychological climate } & 6.4 & 40.4 & 53.2\end{array}$

Using the method of Correlation it is examined the impact that the above-mentioned Teaching Staff's aspects cause on its daily performance (Table 3 ).

Table 3: Correlations of Internal School Environment Factors

\begin{tabular}{lc}
\hline Factors of Internal School Environment & Result \\
\hline Q.1.1.b.Location (site of installation)/Close Environment of the school unit & 0.37 \\
Q.1.2.b.Building / Hygiene Conditions & 0.19 \\
Q.1.3.b.Organizational / Operational Structure of the school unit & 0.21 \\
Q.1.4.b.Behaviour of the Principal & 0.27 \\
Q.1.5.b.Behaviour of the Colleagues & 0.29 \\
Q.1.6.b.Behaviour of the students/student councils & 0.10 \\
Q.1.7.b.Students' performance & 0.09 \\
Q.1.8.b.Head teachers' institutional weakness to control the students' behaviour & -0.30 \\
Q.1.9.b.Technological Equipment / Support Staff & 0.03 \\
Q.1.10.b.Development of Learning Projects & 0.40 \\
Q.1.11.b.Evaluation of teachers and educational work & 0.15 \\
Q.1.12.b.Head teachers' Incentive Policy & 0.30 \\
Q.1.13.b.The in-school natural (physical) climate & -0.22 \\
Q.1.14.b.The in-school psychological climate & -0.27 \\
\hline
\end{tabular}

\section{Discussion and Conclusions}

Totally, they have been collected primary data about 14 factors in the internal school environment. It appears that the majority of these, namely 11, influences positively the teaching staff of Secondary Education at Karditsa and therefore the more positive the view on these factors is, the more positively they affect teachers' work. Three factors affect teachers' work negatively, so the more negative the view, held by the Teaching Staff, on them is the more negatively teachers' work is affected.

On the basis of both the results of the conducted research and the elements of Greek and foreign literature it is confirmed that in relation to the internal environment special reference should be made to the new institution of learning projects that can affect positively teachers in teaching, in classroom management, in collaboration and communication with students and in their effectiveness. This new applied teaching method helps teachers have a better classroom management and improve the school climate. The positive effect of the location and the close environment of the school unit is notable also. The choice of the location of a school unit is an option that affects the teaching staff's quality of experience at Karditsa and this seems to be particularly important. Furthermore, from the investigation it is confirmed that the Head teachers' incentive policy of a school unit, the behaviour of the Principal and colleagues, the school organization and the management, the building and hygienic conditions and the students' behaviour have a positive effect on teachers. Animate and inanimate material of schools is a key factor for the view and the experiences at the workplace. The more positively teachers of Secondary Education evaluate these factors, the more positive they feel in the workplace.

Teachers of Secondary Education at Karditsa are negatively affected by institutional inability of the school administration to control students' attitudes and behaviours, which have negative effect on the school climate. The control of indiscipline and delinquent behaviour, the compliance and the respect of students for the operating rules of the school and their discipline facilitate the management of the classroom and teachers' work. The in-school mental and physical climate have negative impact on teachers of Secondary Education. The ergonomic of schools, the daily tasks, duties and satisfaction are key factors for the effectiveness of teachers in Secondary Education.

\section{Limitations and Directions for Further Research}

From the data that have been collected and a research in Greek and Foreign Literature it has been found that a further investigation is needed on the institutional weakness of the Principal of schools to control attitudes and behaviours of students in order to exist a good school climate. In connection with management of schools it is required research on the policy of incentives that can be followed and the implications that it could have for the teaching staff. Additionally, the 
impact of educational projects to teachers is offered for investigation. Finally, mainly the location of schools, the close environment from the urban center and then the ergonomic of the school buildings are a wide field of research on regarding the highlighting of positive or negative consequences experienced by the living material of them.

\section{References}

Andrews, M., Duncombe, W., \& Yinger, J. (2002). Revisiting economies of size in American education: are we any closer to a consensus?. Economics of Education Review, 21(3), 245-262.

Athanasoula-Reppa, A. (2008). Educational Administration and Organizational Behaviour. Athens: Ellin. (in Greek)

Baba, V., Galperin, B. \& Lituchy, T. (1999). Occupational mental health: a study of work-related depression among nurses in the Caribbean. International Journal of Nursing Studies, 36(2), 163-169. doi: 10.1016/S0020-7489(99)00002-4

Bauer, J., Stamm, A., Virnich, K., Wissing, K., Móller, U., Wirsching, M. \& Schaarschmidt, U. (2006). Correlation between burnout syndrome and psychological and psychosomatic symptoms among teachers. International Archives of Occupational and Environment Health, 79 (3), 199-204. doi: 10.1007/s420-005-0050-y

Berry, B., Smylie, M., \& Fuller. E. (2008). Understanding Teacher Working Conditions: A Review and Look to the Future. Center for Teaching Quality. Retrieved September 14, 2013 from: http://166.78.18.218/sites/default/files/Understanding\%20Teacher\%

Bishop, Y. M., Finberg, S. E. \& Holland, P. W. (2007). Discrete Multivate Analysis: Theory and Applications. New York: Springer Science and Business Media Publishing [eBook version]. Retrieved on October 4, 2013 from: http://www.google.gr/books?

Buckley, J., Schneider, M., \& Shang, Y. (2005). Fix It and They Might Stay: School Facility Quality and Teacher Retention in Washington, D.C.. Teachers College Record, 107(5), 1107-1123. doi: 10.2466/pr0.1992.71.3f.1331

Burkhardt, H., \& Schoenfeld, A. (2003). Improving Educational Research: Toward a More Useful, More Influential, and Better-Funded Enterprise. Educational Researcher, 32(9), 3-14. doi: 10.2466/pr0.1992.71.3f.1331

Chapain, R. (2008). Stress and psychological distress among trainee secondary teachers in England. Educational Psychology: An International Journal of Experimental Educational Psychology, 28 (2), 195-209. doi: 10.1080/01443410701491858

Chatzichristou, C. (2004). Facing anxiogenic situations. Athens: Typothito-G. Dardanos. (in Greek)

Coleman, P. \& Collinge, J. (1991). In the Web: Internal and External Influences Affecting School Improvement. School Effectiveness and School Improvement: An International Journal of Research, Policy and Practice, 2 (4), 262-285. doi: 10.1080/0924345910020402

Cox, H. \& Wood, J. (1980). Organizational structure and professional alienation: The case of public school teachers. Peabody Journal of Education, 58 (1), 1-6. doi: 10.1080/01619568009538304

Dannenberg, A., Jackson, R., Frumkin, H., Schieber, R., Pratt, M., Kochtitzky, C. \& Tilson, H. (2003). The Impact of Community Design and Land-Use Choices on Public Health: A Scientific Research Agenda. American Journal of Public Health: 93 (9), 1500-1508. doi: $10.2105 /$ AJPH.93.9.1500

Delvaux, E., Vanhoof, J., Tuytens, M., Vekeman, E., Devos, G. \& Van Petegem, P. (2013). How may teacher evaluation have an impact on professional development? A multilevel Analysis. Teaching and Teacher Education, 36, 1-11.

Galand, B., Lecocq, C. \& Philippot, P. (2007). School violence and teacher professional disengagement. British Journal of Educational Psychology, 77 (2), 465-477. doi: 10.1348/000709906X114571

Glarentzou, E., Dellaportas, D., Katsikas, C., Kolentzou P., Mpourdi, M., Ntigrintaki, D.\& Chatzistamatis, K. (2011). Environment, Working Conditions and their Impacts on Health of Teachers. Post to 9th Congress of OLME, 7 to 9 April 2011, Volos. Retrieved on September 20, 2013 from: http://dialogos-9osynedrio-olme.blogspot.gr/2011/03/2_3412.html (in Greek)

Gotovos, A., Mavrogiorgos, G. \& Papakonstantinou, P. (2000). Reviewed Pedagogy and Education Act. Athens: Gutenberg. (in Greek)

Greek Ministry of Employment (1992). Hygiene and Safety in the workplace. Athens: Greek Ministry of Employment. (in Greek)

Hair, J. F., Black, W. C., Babin, B. J. \& Anderson, R.E. (2010). Multivariate data analysis, 2nd Edition., Englewood, New Jersey: Prentice Hall Higher Education.

Hallinger, P. (2003). Leading educational change: Reflections on the practice of instructional and transformational leadership. Cambridge Journal of education, 33(3), 329-352. doi: 10.1080/0305764032000122005

Hamre, B., Pianta, R., Downer, J. \& Mashburn A. (2008). Teachers' Perceptions of Conflict with Young Students: Looking beyond Problem Behaviors. Social Development, 17 (1), 115-136. doi: 10.1111/j.1467-9507.2007.00418.x

Hanaken, J., Bakker, B. \& Schaufeli, W. (2006). Burnout and work engagement among teachers. Journal of School Psychology, 43 (6), 495-513. doi: 10.1016/j.jsp.2005.11.001

Hargreaves, A. (2006). Educational Change Over Time? The Sustainability and Nonsustainability of Three Decades of Secondary School Change and Continuity. Educational Administration Quarterly, 42 (1), 3-41. doi: 10.1177/0013161X05277975

Hillson, D. (2009). Managing Risks in Projects-Fundamentals of Project Management. Surrey, UK: Gower Publishing Limited.

Horne-Martin, S. (2005). The classroom environment and children's performance. Is there a relationship? In Spencer, C. kaı Blades, M., (Eds). Children and their Environments. Learning, Using and Designing Spaces. $2^{\text {nd }}$ Edition (pp. 91-107). New York: Cambridge University Press.

Howard, S. \& Johnson, B. (2004). Resilient teachers: Resisting stress and burnout. Social Psychology of Education, 7, 399420.Retrieved on October 29, 2013 from: http://link.springer.com/article/10.1007\%2Fs11218-004-0975-0?Ll=true\#page-1

lacovides,A., Fountoulakis, K., Moysidou, C. 7 Lerodiakonou, C. (1999). Burnout in nursing staff: is there a relationship between depression and burnout?. The International Journal of Psychiatry in Medicine, 29 (4), 421-433. doi: 10.2190/5YHH-4CVF-99M4MJ28 
Jenkins, H., Clinton, K., Purushotma, R., Robison, A. \& Weigel, M. (2009). Confronting the Challenges of Participatory Culture: Media Education for the 21st Century. Chicago, Illinois: MacArthur Foundation.

Kampourakis, G. (2005). The acoustic of classrooms and the impacts on communication, Technical Chronicles, 1, 1-31. (in Greek)

Kokkinos, C. (2007). Job stressors, personality and burnout in primary school teachers. British Journal of Educational Psychology, 77(1), 229-243. doi: 10.1348/000709905X90344

Kountouras, M. (1985). Quit the Schools. Athens: Gnosi. (in Greek)

Kouri, C. (1999). Wait for the Bus: How Low country School Site Selection and Design Deter Walking to School and Contribute to Urban Sprawl. Charleston: South Carolina Coastal Conservation League.

Kyriacou, C. (2001). Teacher Stress: Directions for future research. Educational Review, 53 (1), 27-35. doi: 10.1080/00131910120033628

Mallet, P., \& Paty, B. (1999). How French counsellors treat school violence: An adult-centered approach. International Journal for the Advancement of Counselling, 21 (4), 279-300. Retrieved on 25 November, 2013 from: http://link.springer.com/article/10.1023/A:1005678410105\#page-1

Maslach, C., (1987). Burnout research in the social sciences: a critique. Journal of Social Service Research, 10, 95-105.

Olivier, M. \& Venter, D. (2003). The extent and causes of stress in teachers in the George region. South African Journal of Education, 23 (3), 186-192.

Organization for Economic Co-Operation and Development (2007). Education at a glance. Paris: Organization for Economic CoOperation and Development (OECD).

Platsidou, M. \& Agaliotis, I. (2008). Burnout, Job Satisfaction and Instructional Assignment-related Sources of Stress in Greek Special Education Teachers. International Journal of Disability, Development and Education Teachers, 55, I, 61-76. doi: 10.1080/10349120701654613

Pappa, V. (2006). Stress of the teachers and the factors that contribute to Burnout. Review of Educational Affairs, 11, 135-142. (In Greek)

Papastylianou, A., Kaila, M. \& Polychronopoulos, M. (2009). Teachers' burnout, depression, role ambiguity and conflict. Social Psychology of Education, 12 (3), 295-314. doi: 10.1007/s11218-008-9086-7

Pucher, J., \& Dijkstra, L. (2003). Promoting safe walking and cycling to improve public health: lessons from The Netherlands and Germany. American Journal of Public Health, 93, 1509-1516. doi: 10.2105/AJPH.93.9.1509

Saitis, C. (2008). Educational policy and administration. Athens: O.A.E.D. [eBook version]. Retrieved July 4, 2013 from: http://repository.edulll.gr/edulll/handle/10795/1093 (in Greek)

Schneider, M. (2002). Do school facilities affect academic outcomes?. Washington, DC: National Clearing House for Educational Facilities.

Schneider, M. (2003). Linking school facility conditions to teacher satisfaction and success. Washington, DC: National Clearinghouse for Educational Facilities.

Sdrolias, L., Terzidis, K. and Polyzos, S. (2003). Mental alienation of the business staff from their workplace. Conceptual Approach of the phenomenon -Causes-Symptoms. Review of Economic Sciences, 3, 101-118. (in Greek)

Shalley, C., Zhou, J. \& Oldham, G. (2004). The Effects of Personal and Contextual Characteristics on Creativity: Where Should We Go from Here?. Journal of Management, 30 (6), 933-958. doi: 10.1016/j.jm.2004.06.007

Shannon, P. (2000). A Marxist reading of reading education. Cultural Logic: Special Issue: Marxism and Education, 4 (1), $1-11$. Retrieved November 10, 2013 from: http://clogic.eserver.org/4-1/shannon.html

Shield, B. \& Dockrell, J. (2004). External and internal noise surveys of London primary schools. Journal of the American Statistical Association, 115, 730-738. Retrieved on 2 December, 2013 from: http://eprints.ioe.ac.uk/800/

Supovitz, J. \& Turner, H. (2000). The Effects of Professional Development on Science Teaching Practices and Classroom Culture. Journal of Research in Science Teaching, 37 (9), 963-980. doi: 10.1002/1098-2736(200011)37:9<963::AID-TEA6>3.0.CO;2-0

Smilansky, J. (2011). External and internal correlates of teachers' satisfaction and willingness to report stress. British Journal of Educational Psychology, 54 (1), 84-92. doi: 10.1111/j.2044-8279.1984.tb00847.x

Tennant, C. (2001). Work-related stress and depressive disorders. Journal of Psychosomatic Research, 51 (5), 697-704.

Thomson, W. \& Wendt, J. (1995). Contribution of hardiness and school climate to alienation experience by student teachers. The Journal of Educational Research, 88 (5), 269-274. doi: 10.1080/00220671.1995.9941310

Troman, G. (2000). Teacher Stress in the Low-Trust Society. British Journal of Sociology of Education, 21 (3), $331-353$. doi: $10.1080 / 713655357$

Uline, C. \& Tschannen-Moran, M. (2008). The walls speak: the interplay of quality facilities, school climate, and student achievement. Journal of Educational Administration, 46 (1), 55 - 73. doi: 10.1108/09578230810849817

Van Dick, R. \& Ulrich Wagner, U. (2001). Stress and strain in teaching: A structural equation approach. British Journal of Educational Psychology, 71 (2), 243-259. doi: 10.1348/000709901158505

Wakefield, J. (1992). The concept of mental disorder: On the boundary between biological facts and social values. Psychother Psychosom, 47(3), 373-388. doi: 10.1037/0003-066X.47.3.373 